\title{
Brazilian Innovation Tax Policy and International Investment: Evidence from United States Multinationals and International Patent Applications*
}

\section{Política Fiscal de Inovação Brasileira e Investimentos Internacionais: Evidências de Multinacionais Norte-Americanas e Depósitos Internacionais de Patentes}

Daniel Gama e Colombo ${ }^{a, b}$ id

\begin{abstract}
In the last decades, multinational enterprises (MNEs) have increased their internationalization levels of innovation activities. Brazil has benefited from such changes and received increasing investment from MNEs. In 2005, the federal government approved new tax incentives (Law 11,196/05) to foster business innovation in the country by reducing the tax cost of research and development (RED) activities. This paper investigates whether these tax breaks have attracted 'footloose RED', diverting international investment from other economies. After a literature review on locational factors for REBD attraction and an analysis of the Brazilian case, an econometric model is presented, using data on RED investment by U.S. MNEs and priority patent applications. No evidence that Brazilian tax incentives have attracted international RED from alternative host countries is found. This result is in accordance with previous research suggesting international RED performed in Brazil is mainly adaptive and support-oriented and, for this reason, tax incentives are not a primary attraction factor. It also suggests that claims that international fiscal competition lead to a zero-sum game may be unfounded for the Brazilian case.
\end{abstract}

Keywords: Innovation policy. International investment. Tax incentives.

Resumo: Nas últimas décadas, conglomerados multinacionais (MNEs) aumentaram o nível de internacionalização de suas atividades de inovação. O Brasil beneficiou-se dessa mudança e recebeu valores crescentes de investimentos de grupos estrangeiros. Em 2005, o governo federal aprovou um pacote de incentivos fiscais (Lei 11.196/05) para fomentar a inovação empresarial no país reduzindo o custo fiscal de projetos de pesquisa e desenvolvimento (PEBD). Este artigo investiga se essa redução tributária atraiu recursos

Instituto Nacional de Estudos e Pesquisas Educacionais Anísio Teixeira (Inep), Diretoria de Estudos Educacionais. Brasília, Brasil.

b Centro Universitário UNIEURO. Brasília, Brasil.

* $\quad$ Dedicated to the memory of Prof. Milton de Abreu Campanário, who made numerous contributions to this paper. An earlier version of this research was part of the doctoral thesis submitted to the Department of Economics of the School of Economics, Business and Accounting of the University of Sao Paulo (FEA-USP). I thank Prof. Helio Nogueira da Cruz (FEA-USP) and Prof. Jorge Martinez-Vazquez (Andrew Young School of Policy Studies of Georgia State University) for their comments and support to this research. I acknowledge the financial support of CAPES (Coordination for the Improvement of Higher Education Personnel) and FIPE (Institute of Economic Research). Access to PINTEC confidential microdata granted by permission of IBGE (03605.000637/2015-70). 
de PESD em detrimento de economias concorrentes. Após uma revisão da literatura sobre fatores de atração de PEBD e uma análise do caso brasileiro, é proposto um modelo econométrico utilizando dados de investimentos em PED de MNEs norte-americanas e de depósitos prioritários de patentes. Não é encontrada qualquer evidência de que os incentivos fiscais brasileiros tenham atraído PẺD em prejuízo de destinos alternativos. Esse resultado encontra-se de acordo com pesquisas anteriores que sugerem que o PED realizado no Brasil por MNEs é primordialmente de natureza adaptativa e voltada ao suporte das atividades locais, e que, por esse motivo, incentivos tributários não são de primeira importância na atração de investimentos. As conclusões do estudo refutam para o caso brasileiro o argumento de que competição fiscal entre países pode levar a um jogo de soma-zero.

Palavras-chave: Incentivos fiscais. Investimento internacional. Política de inovação.

JEL Classification: $\mathrm{O} 23 ; \mathrm{O} 38 ; \mathrm{O} 54$.

1 Introduction

Internationalization of research and development (REDD) activities has changed the landscape of industrial innovation substantially in the last decades. Multinational enterprises (MNEs) concentrate a large part of this investment (UNCTAD, 2005a; OECD, 2008), and by offshoring RED they can divide resources and projects among several geographic areas, either to exploit local competitive advantages or to support local production and sales. So far Brazil has received a small but growing share of international innovation funds, following the inflow of total foreign direct investment (FDI). ${ }^{1}$

To foster RED spending and attract international RED to the country, the Federal Government enacted Law 11,196/05, consolidating and expanding tax incentives to companies investing in scientific and technological development. However, this strategy has been criticized in economic literature as 'beggar-thy-neighbor' schemes at the international level (BLOOM; GRIFFITH, 2001; WILSON, 2009), as MNEs relocate their RED to take advantage of local tax breaks. ${ }^{2}$

The objective of this paper is to investigate whether this argument is applicable to the Brazilian tax policy. Based on a review of the relevant literature and data on RED internalization and its drivers, an econometric model is presented to test whether there is evidence that tax breaks granted by Brazilian authorities have diverted investment from other sources, attracting 'footloose RED' (BLOOM; GRIFFITH, 2001). Two distinct sets of panel data are used for estimation: RED investment of United States (U.S.) MNEs abroad; and international priority patent applications.

$\overline{1 \quad \text { See section 3.1. }}$.

2 As discussed in section 2.2. 
The paper is structured as follows: the second section discusses RED internationalization, identifying its main drivers and analyzing the role of tax policy. The third section is dedicated to the Brazilian case, with data on international investment directed to the country and analyzing the innovation tax policy introduced by the government. The fourth section presents the econometric analysis, describing the empirical model and its results. The fifth and last section concludes the study by discussing the findings and its policy implications.

\section{International lnvestment in Innovation}

RED was one of the last activities of the value chain to be internationalized by multinational groups after distribution, sales and production (OECD, 2011). The main explanation for this is the vital importance of technology for business, along with its tacit nature, economies of scale for laboratory equipment and research, difficulty of knowledge transfer and the risk of information leaks (OECD, 2008).

Although there is evidence of international RED dispersion since the 1960s (HIRSCHEY; CAVES, 1981), this trend gained strength as from the 1980s (OECD, 2008), when international competition drove MNEs to outsource part of these activities to foreign affiliates or subcontracted to specialized firms abroad. Studies identified a group of "centrifugal forces" (HIRSCHEY; CAVES, 1981) that counterbalance RED centralization: support for production and adaptation of products to foreign markets; development or customization of technology for natural resource extraction; technology seeking the capture of spillovers; access to low cost or highly skilled personnel; and proximity to customers or partners (THOMSON, 2009; OECD, 2008). A recent literature also pointed out the role of global value chains and of the fragmentation of production across different countries as drivers of RED internationalization, for co-location and feedback effects between different activities increase the benefits of developing innovative activities abroad (BELDERBOS et al., 2016).

In spite of these drivers, the majority of MNEs' RED is still performed at the home country (OECD, 2014a). By 2016, only 43\% of MNEs planned to spend more than one-fifth of their RED budget abroad (UNCTAD, 2014). The chemical and pharmaceutical industries are the ones that most internationalized their innovation efforts (EUROPEAN COMISSION, 2012; UNCTAD, 2005b).

The largest part of internationalized RED is mostly originated from and directed to developed countries (OECD, 2008). Nonetheless, emerging countries are becoming relevant players in this field, attracting a growing share of resources. However, as this requires a minimum level of qualified labor and infrastructure, only few developing countries manage to receive a significant portion of investments (UNCTAD, 2005b). The BRICS economies are the most notorious examples of this 
trend, as they have succeeded in attracting a growing share of innovation investments recently (BELDERBOS et al., 2016).

Developing countries are not only attracting foreign capital, but their MNEs are starting to internationalize REDD. This new trend is led mostly by Chinese multinationals, followed by a small number of Indian, Korean and Brazilian groups (UNCTAD, 2005a; BELDERBOS et al., 2016). The motives of these companies are slightly different from developed countries' MNEs, as they are more interested in complying with requirements to enter foreign markets and obtaining new technologies and skills (OECD, 2008).

\subsection{Types of International R\&D and Drivers of Investment Location}

The pioneer works dedicated to factors influencing the location of international RED date from the 1960s and 1970s (DUNNING, 1958; SAFARIAN, 1966; U.S. TARIFF COMMISSION, 1973). The influential framework proposed by Dunning $(1980,1988,1994)$ suggests that firms engage in different types of activities abroad - including RED - depending on the sets of ownership, location and internalization advantages (DUNNING, 1980) that they have or intend to obtain.

According to this framework, there are four basic categories of technological innovation undertaken by MNEs in other countries (DUNNING, 1994; DUNNING; NARULA, 1995). The first and most common is adaptive RED. This is the main investment received by emerging economies, and it is meant to adapt products to local regulations or consumer preferences, preparing them to be manufactured or sold in the local market (UNCTAD, 2005a). Internationalization drivers in this case are weak, and development should be limited, local and demand-oriented, not affecting core business technology or the innovation strategy of the group at the international level. As a consequence, the main variable for determining the RED level should be market size or level of sales of the respective affiliate or local representative. In some cases, economies of scale may dictate that one facility works as a base for an entire region, so export levels might well be significant. On the supply-side, the availability of a minimally qualified workforce is necessary, although the required skills are more those of applied scientists and engineers than of research scientists (DUNNING, 1994).

The second type is the research on basic materials, mainly natural resources or immobile inputs, or on products that require constant testing and interaction with the customer. It is considered more research-intensive than pure adaptive $\mathrm{REB}$, as it may substantially improve or alter products, and therefore it requires a stronger local scientific base (DUNNING, 1994; DUNNING; NARULA, 1995).

"Rationalized research" (DUNNING, 1994) or "innovative RED" (UNCTAD, $2005 \mathrm{~b}$ ) is the third class of internationalized innovation activities. In these cases, 
MNEs find competitive advantages in undertaking RED not only for market exploitation, but also to supplement or expand technology development out of the home country. The local site becomes a technology exporter for other labs in the RED network. Supply-side factors play a more pivotal role, and the critical one is the presence of a substantial pool of highly qualified scientists and engineers in specific areas. This directs this type of investment to developed economies, although South-East Asia has attracted a group of facilities, and there are special cases of innovative RED in other countries, such as the automotive industry in Latin America (UNCTAD, 2005a) and, more recently, the case of pharmaceutical companies in Brazil (DIAS et al., 2013). Presence in, and interaction with, universities is also a relevant feature, as it may boost innovation efforts. In addition, as the technology developed in these centers may have a strategic competitive advantage, an institutional framework protecting intellectual property rights is a crucial requirement.

The last type is a specific case of RED offshoring known as 'strategic asset-seeking' (DUNNING, 1994) or 'monitoring outposts' (UNCTAD, 2005a), mainly used by companies to access and benefit from knowledge spillovers arising from clusters and regions with a concentration of innovative firms (CANTWELL; JANNE, 1999; LE BAS; SIERRA, 2002; JINDRA; HASSAN; CANTNER, 2016; SIEDSCHLAG et al., 2013). It is "mainly drawn to countries boasting world class clusters of technological and industrial activity" (UNCTAD, 2005a, p. 165), and, for this reason, it happens almost exclusively in developed economies (DUNNING; NARULA, 1995). The attraction factor, in this case, is the presence of the cluster. The main examples are the Silicon Valley electronics/information technology and Boston pharmaceuticals industries.

Since the advance of international RED in the 1980s, empirical studies tried to identify and test the strength of locational attraction factors. ${ }^{3}$ Surveys are generally used for assessing future trends or gaining insights into the motive and rationale of innovation strategies (EDLER; MEYER-KRAHMER; REGER, 2002; UNCTAD, 2005b; THURSBY, J.; THURSBY, M., 2006). Data analysis studies and reports (OECD, 2008, 2011, 2014a; UNCTAD, 2005a; EUROPEAN COMISSION, 2012) rely mainly on country data, descriptive statistics and time series along with literature surveys, presenting a comprehensive description of the situation and future trends for companies`investments policies. In general, findings of these empirical studies matched predictions of Dunning's (1994) theoretical framework. Relevant factors may rank differently, but demand is still the main attraction feature, although it plays a more significant role for emerging countries, in light of the nature of the majority of RED activities developed therein.

Econometric models tested if country features influence the innovation investment of international groups and other variables. The main relevant characteristics

3 For literature surveys on this subject, see Hatem and Py (2008) and Hall (2011). 
stressed in these studies are: market size or affiliates` sales levels, as confirmed in nearly all studies reviewed (HATEM, 2009; KUMAR, 2001; CANTWELL; PISCITELLO, 2002; JONES; TEEGEN, 2003; ATHUKORALA; KOHPAIBOON, 2006); agglomeration economies (HATEM, 2009; JINDRA; HASSAN; CANTNER,2016; SIEDSCHLAG et al., 2013); knowledge externalities (JINDRA; HASSAN; CANTNER, 2016); human capital (SIEDSCHLAG et al., 2013; CANTWELL; PISCITELLO, 2002; JONES; TEEGEN, 2003); RED intensity in the region (SIEDSCHLAG et al., 2013;SHIMIZUTANI; TODO, 2008; BELDERBOS; LYKOGIANNI; VEUGELLERS, 2008; ATHUKORALA; KOHPAIBOON, 2006); and academic research (BELDERBOS et al., 2014).

\subsection{Tax Incentives and Foreign R\&D Attraction: the 'Footloose R\&D' Argument.}

The analysis on the relevance of tax incentives as factors of attraction of international RED is a recent development of and the intersection point between two important contemporary debates in innovation economics: (a) the impact of these policies on private RED; and (b) the main drivers of innovation investment location.

Empirical evidence provided by companies`surveys do not grant these incentives primary importance in the attraction of new investment (THURSBY; THURSBY, 2006). They seem to matter more in developed nations, although they are still less relevant than other factors such as intellectual property protection, collaboration with universities and quality of RED systems. Governments, nonetheless, use this instrument to attract innovation activities to their territories due to their positive externalities (KÖHLER; LAREDO; RAMMER, 2012).

Another point that has received considerable attention in empirical reports is the corporate strategy of reallocating money from one country to another to take advantage of fiscal benefits without raising global expenditure. This was called by Bloom and Griffith (2001) as 'footloose RED', and the issue was discussed in OECD (2013a). This report presented a quantitative model to analyze the effective value and impact of tax measures on the location of expenditure and knowledge-based capital. One of the findings was that international competition for RED may lead to overall loss of tax revenues without the corresponding increase in innovation, calling therefore for international cooperation and consistency between national policies. In OECD (2014a), the topic was once again highlighted, observing that individual tax alleviation policies can generate a zero-sum game at the international level, which may be considerably costly considering that around $90 \%$ of the total RED worldwide is in MNEs` hands. Similar conclusions were reached by Köhler, Laredo and Rammer (2012) and in the report of the French Assemblée Nationale (2010). 
In the academic literature, however, this topic has not yet been extensively discussed (Thomson [2009] described it as being "at a nascent stage"). Pioneer studies on the subject date from the 1990s (HINES JR., 1993, 1994, 1995). The most influential paper on this topic is Bloom and Griffith (2001), that developed the 'footloose RED' argument. By analyzing a panel of countries, the authors found that business RED in the United Kingdom was attracted to other countries by tax incentives. Wilson (2009) conducted a similar study focusing on the competition between U.S. states, concluding that "nearly all" RED augmentation caused by tax reductions was caused by relocation between states. Considering European MNEs only, Knoll, Baumann and Riedel (2014) found that nearly 80\% of the RED increase caused by tax incentives in one country is due to relocation. Belderbos et al. (2016) assessed the effect of tax incentives and other cost factors for a group of 'global cities', and their results indicate that tax incentives attract innovation investments with an elasticity of 0.9. Hines Jr. (1995) presented evidence that local REBD and imported technology are substitutes, and that MNEs respond to an increase in royalty tax rates by increasing local RED. Finally, Dischinger and Riedel (2010) and McKenzie and Sershun (2010) also concluded that RED tax incentives affected international flow of investment.

These results were challenged by a second group of studies that, in essence, followed the empirical literature of drivers of internationalization of RED. Their main arguments are: (a) that once an adequate number of country features are added as controls, tax costs or incentives lose statistical significance, meaning that other factors are more relevant for location of innovation activities; and (b) that fierce international competition does not allow substantial relocation results to emerge or be sustainable, as tax incentives granted by one country are likely to be counterbalanced by similar provisions abroad (OECD, 2014a; KÖHLER; LAREDO; RAMMER, 2011). Athukorala and Kohpaiboon (2006) defended the first point by running two groups of estimates: the first one with a full set of control variables that did not find significance for tax incentives; and a second reducing the number of controls that generated significant results similar to Hines Jr. (1995) and Bloom and Griffith (2001). Based on such results, they argued that the specification used in such studies was biased by omitted variables. In the same sense, Thomson (2009) found no evidence "to support the hypothesis that tax incentives are effective in either inducing MNEs' affiliates to undertake additional RED or to encourage additional international RED contracts" (THOMSON, 2009, p. 40).

The paper by Hines Jr. and Jaffe (2001) presented an alternative impact of tax incentives on international investment. Focusing exclusively on the firm `s dilemma of local versus foreign RED, the study concluded that these two activities are actually complementary, and therefore a tax decrease in either country is more 
likely to increase the levels of innovation in both locations. Such hypothesis, however, was not considered in later analyses.

This literature review suggests that the relocation of innovation investments caused by tax benefits remains an open debate that has not yet reached a level of consensus. Diversity of methods, data and variables lead to different conclusions and interpretations of the behavior of international groups when pursuing technological development worldwide.

A second relevant point is that these studies focused on developed countries, and there is little discussion on whether and to what extent their results apply to emerging economies. As mentioned previously, the type of RED MNEs undertaken in each nation may differ drastically depending on the level of the wealth and technological development, and it is not obvious whether the attraction of fiscal measures would be stronger or weaker in either one.

\section{Analysis of the Brazilian Case}

This section presents and discusses the main features and available data on international innovation investment directed to Brazil. The first subsection discusses the country`s advantages and factors attracting innovation investments from abroad, highlighting the conclusions of the existing empirical literature; and the second briefly describes the fiscal policy implemented by the Brazilian government to foster innovation and discuss possible implications for foreign RED attraction, thus providing the factual basis for the empirical study in the next section.

\subsection{International Innovation in Brazil and Factors of Attraction}

RED offshoring forms part of the total FDI made by international business groups in the country. Since the commercial liberalization and institutional reforms in the 1990s (along with a massive privatization program), Brazil became more appealing to international investors (RUIZ, 2015; HIRATUKA, 2008), and, as a result, FDI directed to the country grew substantially after 1994 .

The figures for the Brazilian innovation system, on the other hand, do not show a positive picture. Brazilian gross expenditure on science and technology in 2013 was around $1.7 \%$ of the country`s GDP, below the OECD average (around $2.4 \%)$ and far from some of its most innovative economies such as South Korea (4.15\%), Israel (4.09\%) and Japan (3.47\%) - OECD (2016).

The challenge to increase the technological efforts of Brazilian industry involves the attraction of international capital. Although foreign companies represent only a small number of the total of industrial firms, they spend more on RED than local enterprises (ARBACHE; GOLDSTEIN; MARQUES, 2011; COSTA, 2005; 
QUEIROZ, 2011). Figure 1 evidences such argument by presenting the average expenditure on RED and innovative activities of firms by origin of controlling capital, according to the 2011 edition of the Industrial Innovation Survey - PINTEC (IBGE, 2013). Although firms owned by nationals represent the great majority of the survey sample, it is clear that their innovation outlays are substantially smaller than those of firms controlled by foreign capital.

Brazil attracts a small but growing fraction of the international resources for REDD. The share of RED by U.S. MNEs offshored to Brazil has risen from around 1\% in 2001 to more than $2.5 \%$ in 2013 . While total international RED by U.S. groups grew on average around $5 \%$ during this period, investment directed to Brazil doubled that rate. Narrowing the focus to the manufacturing sector, investment in Brazil grew by more than $9 \%$, bringing the share of funds to $3.3 \%$ of the total (U.S. BEA, [2016]).

Figure 1 - Number of firms, and average R\&D and innovative activities expenditures by origin of controlling capital - PINTEC 2011. Brazilian R $\$ 1,000.00$.

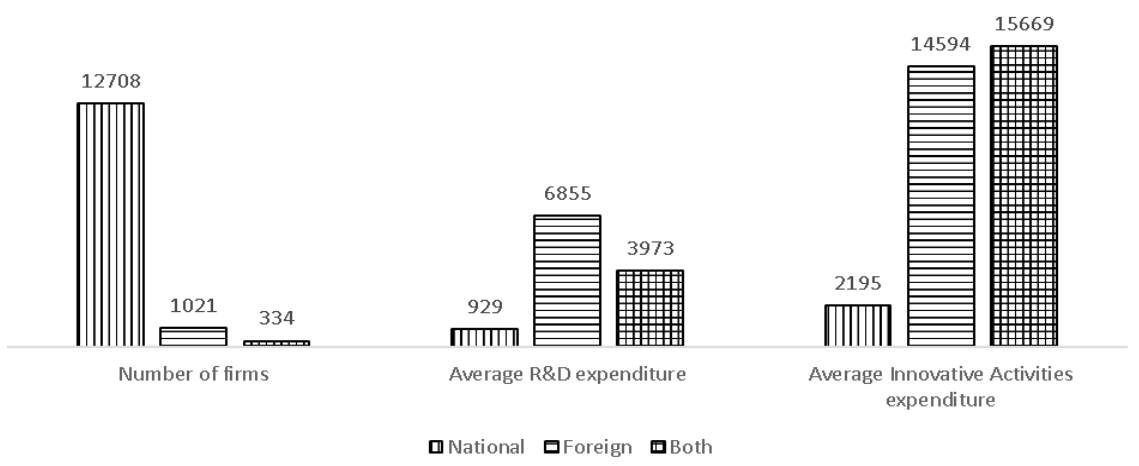

Source: IBGE (2013), confidential microdata.

Ruiz (2015) reported that a great part of RED directed to Brazil refers to transportation equipment, or more specifically, to flex-fuel technologies. Arruda, Barcellos and Tumelero (2014) identified 'current or potential' sectors in which the country has knowledge advantages that may attract foreign capital - agribusiness, information technology, energy, nanotechnology, biotechnology, chemicals, aeronautics, aerospace and defense.

Table 1 displays the origin of foreign controlling capital reported by Brazilian firms present in the 2011 PINTEC survey (IBGE, 2013). Firms controlled by U.S. and European capital represented the great majority of reporting firms, and they also accounted for the greatest part of expenditures in RED and innovative activities. $^{4}$

4 According to the PINTEC, innovative activities include: internal and external RED; acquisition 
As an emerging economy, Brazil attracts more adaptive and support focused REBD, which makes market size and potential growth the most important assets to maintain and increase investment levels, leaving a secondary role for technological capabilities and other supply-side factors. Costa (2005) stressed the importance of market size, although she also identified the relevance of investment trajectories, as companies with long-term local presence have more easily transitioned their technological developments up to the global strategic RED level.

Table 1- Number of firms and total spending on RED and innovative activities by origin of foreign controlling capital - PINTEC 2011

\begin{tabular}{lccc}
\hline \multirow{2}{*}{$\begin{array}{l}\text { Origin of foreign controlling } \\
\text { capital }\end{array}$} & $\begin{array}{c}\text { Number of } \\
\text { firms }\end{array}$ & \multicolumn{2}{c}{ Total spending (U.S. dollars) } \\
\cline { 3 - 4 } Mercosur (other than Brazil) & 60 & 61,694 & Innovative Activities \\
U.S. & 333 & $1,557,604$ & $3,960,398$ \\
Canada and Mexico & 38 & 191,609 & 468,626 \\
Other American countries & 36 & 25,677 & 47,662 \\
Asia & 133 & 228,485 & 919,769 \\
Europe & 740 & $2,372,774$ & $5,206,816$ \\
Oceania or Africa & 15 & 533 & 4,938 \\
\hline
\end{tabular}

Source: IBGE (2013), confidential microdata.

Note: Not included firms controlled exclusively by Brazilian capital. Values in Brazilian reais converted to U.S. dollars according to the exchange rate applicable on Dec. 31 ${ }^{\text {st }}, 2011$.

Relevant empirical literature that tried to track and measure attraction factors for international RED in the country mainly comprise surveys of local affiliates' staff. Most studies found results consistent with the theoretical literature and the innovation investment scenario discussed previously, emphasizing the relevance of market size (QUEIROZ, 2011; ARBACHE; GOLDSTEIN; MARQUES, 2011). According to Arruda, Barcellos and Tumelero (2014), a great number of multinationals that develop RED in Brazil still focus on adaptation and product support. Such affiliates have to present a strong case to convince their parent companies to transfer substantial research to their facilities because of high costs and the bureaucratic requirements they face. The study confirmed that the national and Latin American markets were usually the main factors of attraction, but other features such as geography and specific technological clusters were also important.

of knowledge from third parties; software license or acquisition; acquisition of machinery and equipment; training; introduction of innovations in the market; and industrial design and other measures for production and distribution (IBGE, 2013). 


\subsection{Innovation Tax Policy and Attraction of International R\&D}

In the last decades, the debate on appropriate policies to foster entrepreneurial innovation has regained strength in Brazil. The challenge of creating a business environment that encourages RED without protectionism but enhancing firms' international competitiveness has been the subject of great discussion among scholars and policy-makers. Evidences of this paradigm shift are the three major industrial policy plans issued by the federal government, ${ }^{5}$ along with two National Strategies for Science, Technology and Innovation in 2012 and 2016.

In this new policy context, tax incentives are one of the strategies that gained momentum. Law 11,196/05 granted different tax incentives to companies investing in RED, to encourage firms to raise their expenditure in innovation. The structure of benefits is similar to the practice in other countries, with 'enhanced deduction' of innovation expenditure ${ }^{6}$ and reduction of tax rates that are levied on RED inputs and outputs.

The main objective of the policy was to reduce the tax cost of performing RED in the country. Araujo (2010) estimated the magnitude of such change through the ' $b$-index'. ${ }^{7}$ Such estimate suggests that the benefits approved in 2005 are consistently higher than the average of OECD countries (OECD, 2014b).

The law does not establish any requirement for capital ownership, and therefore does not distinguish between locally-owned companies and affiliates of multinational groups. Table 2 below presents the total number and percentage of potentially innovative firms present in the 2011 PINTEC survey (IBGE, 2013), indicating how many participated in the policy and dividing them by capital origin. Although local firms are the majority of the sample, the percentage of those that obtained tax benefits was substantially higher for the foreign-owned group.

Table 2 - Potentially innovative companies in Brazil, by origin of controlling capital and participation in the innovation tax policy of Law 11,196/05 - PINTEC 2011.

\begin{tabular}{ccc}
\hline \multirow{2}{*}{$\begin{array}{c}\text { Did the firm benefit from tax } \\
\text { incentives in } 2011\end{array}$} & \multicolumn{2}{c}{ No. of firms - Controlling Capital Origin } \\
\cline { 2 - 3 } & Local & Foreign \\
\hline Yes & $322(2.53 \%)$ & $166(16.26 \%)$ \\
No & $12,386(97.47 \%)$ & $855(83.74 \%)$ \\
\hline
\end{tabular}

Source: IBGE (2013), confidential microdata.

Note: Firms with both national and foreign controlling capital not included.

5 The Industrial, Technological and Trade Policy ('Política Industrial, Tecnológica e de Comércio Exterior') in 2003, the Productive Development Policy ('Politica de Desenvolvimento Produtivo') in 2008 and the 'Greater Brazil Plan' ('Plano Brasil Maior') in 2011.

6 Firms deduct from $160 \%$ to $200 \%$ of innovation expenditure from the taxable base of Income Tax (IR) and Social Contribution on Net Profit (CSLL) - art. 17 and 19 of Law 11,196/05.

7 See section 4.1 . 
These numbers suggest that firms with international capital may be in a better position to benefit from the incentives provided by the Brazilian tax policy. They do not mean, however, that such companies or additional innovation funds were necessarily attracted to the country by these incentives. Galina, Camillo and Consoni (2011) reported that innovation policies did not rank as a primary factor for RED attraction in their survey. Queiroz (2011) also concluded that incentives are of secondary importance, and argued that, as more countries approve similar measures, they lose relevance as a decisive factor for new projects or funds. In Arbache, Goldstein and Marques (2011), fiscal benefits again received low frequency of responses when MNEs were questioned about their motivation to perform RED in Brazil. The survey by Arruda, Barcellos and Tumelero (2014) reported that, from the MNEs ` perspective, the tax breaks of Law 11,196/05 are a positive and attractive feature of the local innovation system, but excessive bureaucracy reduces positive impacts.

To consider the applicability of the 'footloose RED' argument to the Brazilian policy, Figure 2 presents the sales and RED expenditure levels of affiliates and subsidiaries of U.S. MNEs in Brazil from 1999 to 2013. The data make a compelling case for the importance of demand-pull factors. The two series presented in the graph are almost perfectly correlated, ${ }^{8}$ not leaving much room for fiscal benefits to be a relevant explanatory factor of the level of innovation investment.

Figure 2 - Sales and RED expenditure levels of U.S. MNEs in Brazil (US\$ millions). Real 2014 values readjusted according to the CPI index.

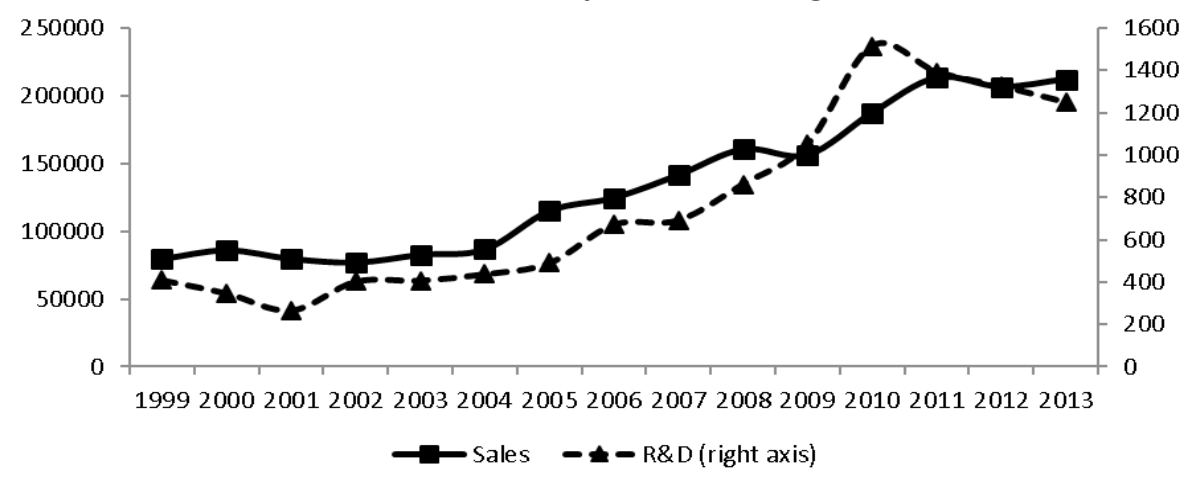

Source: U.S. BEA ([2016]).

On the other hand, Figure 3 shows that the implied subsidy rate represented by the ' 1 -(b-index $)^{\prime}$ is negatively correlated with the share of offshored RED invest-

8 The correlation is 0.96 for the $1999-2013$ period.

9 See section 4.1. 
ment directed to all other countries but Brazil, which may be a result of resources directed to the country to benefit from the fiscal incentives of Law 11,196/05.

To investigate this issue more rigorously, the next section presents a quantitative study that assesses whether the Brazilian policy can be considered a relevant factor in attracting investment from other locations in a 'beggar-thy-neighbor' scheme.

Figure 3 - Implied subsidy rate ('1-(b-index)') for Brazil and share of international innovation investment directed to other countries.

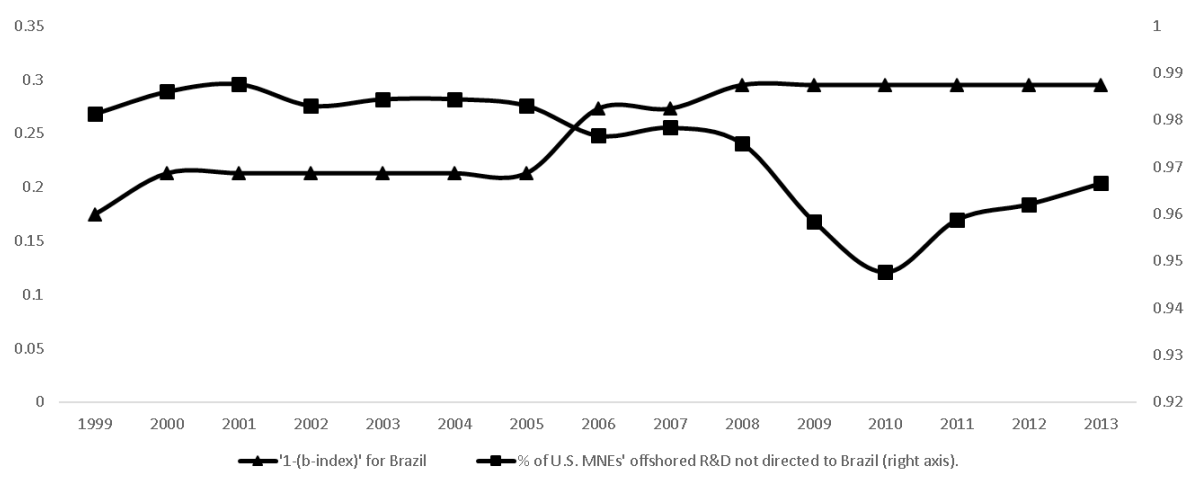

Source: Araujo (2010) and U.S. BEA ([2016]).

\section{Empirical Analysis}

This section describes the empirical study to test for the applicability of the 'footloose RED' argument for the Brazilian innovation tax policy. Unlike other econometric studies discussed in section 2.2, the objective is not to test the relevance of tax policies in general, but only the one implemented in Brazil. The first subsection discusses the data used in the study, the second explains the estimation strategy, and the third presents the results.

\subsection{The Data}

For this analysis, a group of different datasets on several countries were merged. They refer to (a) tax costs and RED incentives in different countries; (b) activities and innovation investment of U.S. MNEs' international affiliates, (c) priority patent applications from different patent offices worldwide; and (d) specific features of each nation, including market and institutional features, and science and technology systems. The data were arranged in an unbalanced panel format covering the period from 1999 to 2013. As the interest lies on the effects of Brazilian policy in other countries, data for Brazil were excluded from all regressions. 
To quantify the tax costs and incentives granted by each country or region, part of the studies discussed in section 2.2 used rates or values extracted directly from tax laws or regulations (WILSON, 2009; MCKENZIE; SERSHUN, 2010; DISCHINGER; RIEDEL, 2010), while another group (THOMSON, 2009; KNOLL; BAUMANN; RIEDEL, 2014) applied the ' $b$-index', an indicator used by OECD to measure the fiscal burden on innovation. ${ }^{10}$ The advantage of the ' $b$-index' is that it allows for a direct comparison of different tax systems, making it particularly useful for quantitative studies at the country level. The ' 1 -(b-index)' is used in this analysis, a transformed version of the " $b$-index"11 that constitutes a more direct measure of tax generosity or "implied subsidy rate" (OECD, 2013b). Index values used in this analysis were estimated by OECD (2014a, 2014b), Stewart, Warda and Atkinson (2012) ${ }_{12}^{12}$ and, for the Brazilian case, Araujo (2010). ${ }^{13}$

But it is important to consider that if firms respond to tax benefits, they do so comparatively. Or, as suggested by Wilson (2009), both in-country and out-of-country tax costs are relevant. Therefore, a correct model specification should take into account not only Brazilian incentives, but how they compare to the ones granted by foreign governments. However, the simultaneous introduction of separate variables representing tax incentives in Brazil and in other countries is not a feasible specification, for the Brazilian policy variable does not vary between countries at each time period. For this reason, the difference between the index for Brazil and for other countries each year is used as the variable to estimate the parameter of interest ('tax incentive'). ${ }^{14}$

Two indicators for innovation activities were mainly used by the econometric studies mentioned in the literature review: RED expenditure by country or state (BLOOM; GRIFFITH, 2001; WILSON, 2009; ATHUKORALA; KOHPAIBOON, 2006), and location of development, application or ownership of intellectual property (DISCHINGER; RIEDEL, 2010; KNOLL; BAUMANN; RIEDEL, 2014), which works as a proxy for locally-generated innovation. ${ }^{15}$ Herein both measures are

10 "The 'b-index' is a measure of the level of pre-tax profit a "representative" company needs to generate to break even on a marginal, unitary outlay on RED" (OECD, 2013b, p. 1). The value is reduced by the tax incentive, for part of the cost is compensated by the benefit.

11 The ' $b$-index' decreases with an increase of the incentive rate. The ' 1 -( $b$-index)', on the other hand, modifies such metric, turning it into a measure of tax generosity. It is directly proportional to the incentive rate.

12 Missing data was extrapolated linearly for short intervals with no significant change in the index.

13 Contrary to the author's estimates, I only reflected the changes of Law 11,196/05 in 2006, the first year in which firms could benefit from the incentives.

14 This specification is appropriate for it captures the relevance of the Brazilian policy controlling for the tax generosity adopted by each country, and it can be used in a panel dataset analysis along with fixed effects and time dummies as covariates.

15 Patent application is challenged as a reliable indicator on the basis that it is heterogeneous among sectors and corporate tax planning may affect location selection (EUROPEAN COMISSION, 2014). 
used in two different models, to consider whether the results are sensitive to such choice: RED spending of U.S. MNEs is considered in the first model, while patent applications are used in the second analysis.

In the case of U.S. MNEs, the study is limited to manufacturing groups with affiliates operating out of the U.S. and positive RED expenditure abroad. The following data were extracted from the U.S. Bureau of Economic Analysis database on Activities of U.S. Affiliates of Foreign Multinational Enterprises (U.S. BEA, [2016]): RED expenditure by manufacturing affiliates in each country per year, in U.S. million dollars, log-linearized ('affiliates' RED'); total value of sales of the respective affiliates in each country per year, in U.S. million dollars, log-linearized ('affiliates' sales'); and export rate of affiliates, or the percentage of total sales to elsewhere other than the host country ('affiliates' export rate').

Data on priority patent applications were extracted from the European Patent Office Statistical Database (EPO, 2015).${ }^{16}$ Following the approach developed and described in Thomson (2013) and de Rassenfosse et al. (2013), the information on country of residence of applicants and inventors is used to obtain a proxy for RED performed or contracted abroad. If the applicant is resident in one country and the inventor in another, it is assumed that the former has transferred resources and implementation of the project to the latter, regardless of the corporate or contract structure used for the transaction, thus constituting a proxy for innovation offshoring. ${ }^{17}$

Based on these guidelines, fractional patent application data were extracted for the 100 countries with the highest number of priority applications in 2013, and such information was grouped according to the country of origin of applicants and inventors. ${ }^{18}$ The cases where these two coincide were excluded, as this investigation focuses exclusively on offshored RED. Only patent applications were retrieved, excluding utility models and new designs. As Brazil mainly receives innovation investment from a limited group of nations, origin of applicants was limited to six countries (U.S., Germany, China, France, United Kingdom and Netherlands),

16 MySQL Code available upon request to the author. A priority application is the first filing aimed at protecting a particular patent. Pursuant to Article 4 of the Paris Convention for the Protection of Industrial Property, once an application has been submitted to any national patent office worldwide, the applicant has 12 months to apply for protection in any other country which is part of the convention, claiming priority over any applications filed after the original submission. De Rassenfosse et al. (2013) maintained that priority applications are a valid and important indicator of innovation because they eliminate the geographic bias and are the closest measure to the date of the invention.

17 The basic idea of the indicator is to consider the applicant as the owner of the intellectual property and funding party of the innovation project. The inventor, on the other hand, is assumed to be the party that effectively carried out the research project, with resources provided by the applicant. As patent applications may have more than one applicant or inventor from different countries, a "fractional counting methodology" (de Rassenfosse et al., 2013) is used, meaning each applicant is assigned with an equal share of each patent filing, and the same is valid for inventors. MySQL Code available upon request to the author. 
responsible for $80 \%$ to $90 \%$ of the yearly innovation investment directed to Brazil. The (log-linearized) number of fractional priority patent applications invented by residents of a country (with applicants from another country) is used as a proxy for international innovation investment directed to such country ('offshored patents').

Data on specific features of invested countries were gathered from different sources with the objective of controlling for factors that, according to the reviewed literature, may influence the decision of MNEs to invest in innovation there. These may be divided into three main groups. The first refers to data on the institutional and policy framework: the "legal system and property rights" index ${ }^{19}$ of the Economic Freedom of the World annual reports (GWARTNEY; LAWSON; HALL, 2015), that provides an indicator of the level of institutional development of each country ('property rights index'). The second group refers to the economic activity level or size of the economy: gross domestic product, in million U.S. dollars (nominal value), log-linearized - 'GDP' (World Bank, [2017]); level of human capital ('human capital'), considered as number of researchers per 1,000 people in the work force (OECD, 2016); and level of industrialization of the economy ('industrialization level'), measured as the industrial sector`s added value as a share of GDP (WORLD BANK [2017]). Indicators on the technological development or innovation system of host nations are also considered: total RED expenditure as a share of GDP per country - 'country RED intensity' (WORLD BANK, [2017]; OECD, 2016); exports of high technology goods as a share of the country`s GDP - 'high-tech exports' (WORLD BANK, [2017]; and stock of patents filed by residents in each local patent office, log-linearized - 'patent stock' (WIPO, [2018])20. Descriptive statistics for all variables mentioned in this section are presented in Table 3.

19 This index is comprised of the following items: judicial independence, impartial courts, protection of property rights, military interference in rule of law and politics, integrity of the legal system, legal enforcement of contracts, regulatory restrictions on the sale of real property, reliability of police and business costs of crime (GWARTNEY; LAWSON; HALL, 2015).

20 This indicator is the result of the sum of all patent files deposited in each country by residents since 1980 up to each year in the dataset, with a depreciation rate of $15 \%$. 
Table 3 - Descriptive statistics of variables used in the empirical analysis

\begin{tabular}{lcccc}
\hline \multicolumn{1}{c}{ Variable } & No. of Obs & No. of Countries & Mean & Overall Std. Dev. \\
\hline affiliates' RED & 643 & 50 & 4.28 & 2.56 \\
offshored patents & 749 & 50 & 4.96 & 2.04 \\
tax incentive & 418 & 37 & 0.15 & 0.12 \\
GDP & 750 & 50 & 12.67 & 1.27 \\
affiliates' sales & 750 & 50 & 9.39 & 1.63 \\
affiliates' export rate & 613 & 50 & 41.41 & 21.12 \\
property rights index & 739 & 50 & 6.62 & 1.66 \\
human capital & 543 & 47 & 5.28 & 3.84 \\
industrialization level & 716 & 49 & 31.75 & 9.57 \\
RED intensity & 574 & 49 & 1.49 & 1.06 \\
high-tech exports & 745 & 50 & 5.42 & 10.99 \\
patent stock & 750 & 50 & 9.4 & 2.42 \\
\hline
\end{tabular}

Source: U.S. BEA ([2016]); EPO (2015); World Bank ([2017]); WIPO (2018); Gwartney, Lawson and Hall (2015); Stewart, Warda and Atkinson (2012); OECD (2014a, 2014b); Araujo (2010).

\subsection{Estimation Strategy}

To assess the correlation of the Brazilian policy with RED investments directed to other countries, two groups of estimates are presented herein. The first uses aggregate data from U.S. MNEs. It is assumed that parent companies, at the beginning of each period, analyze the sales performance of each international affiliate on the last period, along with a series of economic, institutional and technological indicators of each country. Based on such analysis, they decide how much to invest in each international affiliate.

They also study and compare tax incentives for locally performed RED granted by each government in different locations, including the Brazilian tax policy in place each year. It is further assumed that companies know the rate of incentives applicable in each country when they make their decision, as such benefits are in general approved or announced by the government before companies can apply or benefit from them. For this reason, this variable is considered at the same time period as the dependent variable. Assuming that the decision model is linear in its parameters, the described process is presented in the static investment equation (1).

$$
\mathrm{Y}_{\mathrm{it}}=\beta^{\prime} \mathrm{X}_{\mathrm{it}}+\mathrm{f}_{\mathrm{i}}+\mathrm{f}_{\mathrm{t}}+\mathrm{v}_{\mathrm{it}}
$$


Where $Y_{\mathrm{it}}$ is the affiliates' R\&B expenditure in country $i$ at year $t ; X_{\mathrm{it}}$ is the vector of observed explanatory variables; $\beta$ is the vectors of parameters to be estimated; $f_{i}$ controls for countries' fixed effects; $f_{t}$ are time dummies that capture year effects, including the influence of the Brazilian economy and innovation system on MNEs' investment decisions each year; ${ }^{21}$ and $v_{i t}$ represents the unobserved disturbance or error term. The independent variables assumed to affect RED investment directed to each country are the level of tax incentives (as described previously), affiliates' sales, affiliates' export rate; property rights index, human capital, industrialization level, country RED intensity and patent stock. With the exception of the level of tax incentives, all other independent variables are included in the equation with one lagged period.

Wilson (2009) suggested adjustment costs may play a pivotal role in the definition of investments directed to each affiliate. This means parent companies consider values invested in previous years to avoid discontinuing ongoing projects or in light of multi-year planning. To test such argument, a dynamic version of the above model is estimated, including the lagged value of the dependent variable as one of the controls.

The second empirical analysis uses the fractional patent application indicator described above. The investment model follows the one presented in equation (1), but it must take into account that patent filings are outputs of the innovation process. To deal with such feature, it is assumed that innovation projects take one period to mature and result in a priority patent filing. Therefore, the number of offshored patents (the dependent variable $Y_{\mathrm{it}}$ ) observed at time $t$ is the result of decisions made by parent companies at time $t-1$, considering a group of explanatory variables that includes tax incentives for innovation in place in different countries (observed at the same period $t-1$ ), along with the previous period's $(t-2)$ variables for potential demand (country's GDP and high-tech exports), supply factors (human capital, patent stock, industry share of GDP and total country RED intensity) and institutional features (protection of property rights).

Equations' coefficients are estimated using a number of panel data parametric models. The existence of fixed effects is assessed through the Hausman test, and upon confirmation, fixed effects estimator is applied. For comparison purposes, results of the random effects model (WOOLDRIDGE, 2002) are also depicted. For the dynamic specifications, three classes of estimators are used: (a) the fixed effects; (b) Arellano-Bond difference-GMM (ARELLANO; BOND, 1991); and (c) bias-corrected least squares dummy variables estimator - LSDVC (BRUNO, 2005; BUN; KIVIET, 2003). ${ }^{22}$

Alternative versions of the main models are estimated as robustness checks. First, the LSDVC dynamic models are estimated multiple times, gradually excluding each of the control variables, to check if results are sensitive to the models' specifications. Secondly, it may be the case that only a part of alternative host countries may be

21 Variables related to the Brazilian economy would have the same value for all countries in the sample each year, and therefore they cannot be included explicitly in the model specification. group numbers as in this case, outperforming other estimators as system GMM. 
affected by the Brazilian tax policy. Nations with a low volume of funds are less likely to perceive any impact since they probably are not strong competitors for 'footloose RED' funds. Therefore, the main models are estimated taking resources directed to Brazil as a lower limit on the countries to be included in the regressions. Third, the European Commission (2015) recommends that the effects of innovation projects be assessed up to three years after its initial period. Following this recommendation, the fractional patent application model is estimated considering the tax policy variables in $t-2$ and $t-3$, along with the other control variables in $t-3$ and $t-4$, respectively.

\subsection{Presentation of Results}

Table 4 presents the estimated coefficients and other results for the U.S. MNEs' investment model, both for static and dynamic versions. The Hausman test suggests the presence of fixed effects, confirming the relevance of the country's time invariant features for investment decisions, and rendering the random effects estimator inconsistent.

The variable for the level of sales of the respective affiliate presents the strongest and most consistent result in all models. Estimation results suggest the elasticity of RED investment to sales ranges from 0.41 to 0.86 , and the coefficient is significant at a $95 \%$ confidence level for all estimators. The lagged version of the dependent variable also influences the present outcome, and the positive coefficient is significant in all dynamic estimators applied.

The variable for Brazilian policy, on the other hand, did not reach a significant result in any of the estimations, suggesting the country incentives do not influence the decision of these enterprises on how much to invest in other countries. This result implies that the Brazilian policy is not successful in attracting 'footloose RED', and the increase in the incentives rates does not divert resources from other destination options.

Most of the other control variables present a coefficient with the expected positive sign, but without statistical significance on the $95 \%$ confidence level.

Estimation results for the fractional patent application models are displayed in Table 5. In this case, the Hausman test did not confirm the presence of country fixed effects, so the random effects estimator can be considered consistent and efficient. The variable representing market size is again a chief explanatory factor. The GDP coefficient is positive and statistically significant at a $95 \%$ confidence level in three out of five specifications. The elasticity of innovation investment to GDP is estimated to range from 0.24 to 0.87 . The lagged version of the dependent variable is also positive and statistically significant in all models, confirming the influence of past decisions in the definition of current values. 
Table 4 - Results of the main U.S. MNEs model. Dependent Variable: affiliates' RED

\begin{tabular}{|c|c|c|c|c|c|}
\hline \multirow[b]{2}{*}{ Variables } & \multicolumn{5}{|c|}{ Estimator } \\
\hline & $\begin{array}{l}\text { Random } \\
\text { Effects }\end{array}$ & $\begin{array}{c}\text { Fixed } \\
\text { Effects }\end{array}$ & $\begin{array}{c}\text { Fixed } \\
\text { Effects }\end{array}$ & $\begin{array}{c}\text { Arellano- } \\
\text { Bond }\end{array}$ & LSDVC \\
\hline \multirow[t]{2}{*}{ affiliates' RED (t-1) } & & & $0.345 * * *$ & $0.484 * * *$ & $0.417 * * *$ \\
\hline & & & $(0.095)$ & $(0.143)$ & $(0.117)$ \\
\hline \multirow[t]{2}{*}{ tax incentive } & -0.524 & -0.912 & -1.137 & -1.427 & -1.084 \\
\hline & $(0.462)$ & $(0.592)$ & $(0.694)$ & $(0.926)$ & $(1.222)$ \\
\hline \multirow[t]{2}{*}{ affiliates' sales } & $1.048 * * *$ & $0.860 * * *$ & $0.576 * *$ & $0.411^{* * *}$ & $0.542 * *$ \\
\hline & $(0.055)$ & $(0.196)$ & $(0.117)$ & $(0.139)$ & $(0.270)$ \\
\hline \multirow[t]{2}{*}{ property rights index } & 0.054 & 0.049 & 0.046 & 0.034 & 0.036 \\
\hline & $(0.059)$ & $(0.080)$ & $(0.057)$ & $(0.066)$ & $(0.139)$ \\
\hline \multirow[t]{2}{*}{ industrialization level } & -0.010 & 0.028 & $0.050 * * *$ & $0.049 * *$ & 0.048 \\
\hline & $(0.011)$ & $(0.017)$ & $(0.013)$ & $(0.018)$ & $(0.062)$ \\
\hline \multirow[t]{2}{*}{ patent stock } & 0.058 & 0.081 & 0.007 & -0.046 & -0.004 \\
\hline & $(0.076)$ & $(0.276)$ & $(0.207)$ & $(0.233)$ & $(0.487)$ \\
\hline \multirow[t]{2}{*}{ human capital } & -0.031 & 0.037 & 0.041 & 0.029 & 0.038 \\
\hline & $(0.045)$ & $(0.057)$ & $(0.055)$ & $(0.067)$ & $(0.090)$ \\
\hline \multirow[t]{2}{*}{$R \mathcal{} B$ intensity } & $0.734 * * *$ & 0.328 & 0.223 & 0.229 & 0.194 \\
\hline & $(0.145)$ & $(0.267)$ & $(0.203)$ & $(0.233)$ & $(0.436)$ \\
\hline \multirow[t]{2}{*}{ affiliates' export rate } & -0.001 & 0.004 & -0.003 & -0.003 & -0.003 \\
\hline & $(0.003)$ & $(0.007)$ & $(0.005)$ & $(0.006)$ & $(0.009)$ \\
\hline Observations & 241 & 241 & 218 & 218 & 218 \\
\hline R-squared & 0.93 & 0.653 & 0.750 & & \\
\hline No. of countries & 31 & 31 & 31 & 31 & 31 \\
\hline Country FE & Yes & Yes & Yes & Yes & Yes \\
\hline Year dummy & Yes & Yes & Yes & Yes & Yes \\
\hline Hausman Test & \multicolumn{5}{|c|}{$\mathrm{X}^{2}=50.23 ; \mathrm{P}>\mathrm{X}^{2}=0.0002$} \\
\hline
\end{tabular}

Source: Calculated by the author based on Araujo (2010); Gwartney, Lawson and Hall (2015); OECD (2014a, 2014b); Stewart, Warda and Atkinson (2012); U.S. BEA ([2016]); WIPO (2018); World Bank ([2017]).

Note: Standard errors in parentheses. ${ }^{* *} \mathrm{p}<0.01,{ }^{* *} \mathrm{p}<0.05,{ }^{*} \mathrm{p}<0.1$. Coefficient of the constant variable not presented. Reported results of the Hausman Test considered the static specification (columns 1 and 2). 
Brazilian tax incentives again do not seem to be a relevant factor, as the respective variable did not achieve significance in any of the models. Other variables do not achieve statistical significance in most of the regressions, which seems to confirm the results of the previous model.

Robustness checks confirm the main models' findings. ${ }^{23}$ In none of these cases the coefficient related to the Brazilian policy is a statistically significant explanatory variable of the innovation resources directed by MNEs to other nations. Robustness checks also follow the main models' results in showing the relevance of market size, as coefficients of sales levels and GDP are positive and have statistical significance in almost all tested specifications.

Table 5 - Results of the main fractional patent application model. Dependent Variable: offshored patents

\begin{tabular}{|c|c|c|c|c|c|}
\hline \multirow[b]{2}{*}{ Variables } & \multicolumn{5}{|c|}{ Estimator } \\
\hline & $\begin{array}{c}\text { Random } \\
\text { Effects }\end{array}$ & $\begin{array}{c}\text { Fixed } \\
\text { Effects }\end{array}$ & $\begin{array}{l}\text { Fixed } \\
\text { Effects }\end{array}$ & $\begin{array}{l}\text { Arellano- } \\
\text { Bond }\end{array}$ & LSDVC \\
\hline \multirow[t]{2}{*}{$\begin{array}{l}\text { offshored patents } \\
(t-1)\end{array}$} & & & $0.595 * *$ & $0.624 * * *$ & $0.702^{* * *}$ \\
\hline & & & $(0.052)$ & $(0.057)$ & $(0.063)$ \\
\hline \multirow[t]{2}{*}{ tax incentive } & 0.059 & -0.020 & -0.040 & -0.091 & 0.001 \\
\hline & $(0.167)$ & $(0.150)$ & $(0.132)$ & $(0.157)$ & $(0.187)$ \\
\hline \multirow[t]{2}{*}{ GDP } & $0.865 * * *$ & $0.862 * * *$ & 0.324 & 0.309 & $0.236 * *$ \\
\hline & $(0.241)$ & $(0.311)$ & $(0.195)$ & $(0.215)$ & $(0.115)$ \\
\hline \multirow[t]{2}{*}{$\begin{array}{l}\text { property rights } \\
\text { index }\end{array}$} & 0.107 & 0.053 & -0.030 & -0.036 & -0.043 \\
\hline & $(0.067)$ & $(0.060)$ & $(0.040)$ & $(0.043)$ & $(0.037)$ \\
\hline \multirow[t]{2}{*}{ high-tech exports } & 0.006 & -0.001 & -0.004 & -0.004 & -0.003 \\
\hline & $(0.008)$ & $(0.010)$ & $(0.004)$ & $(0.005)$ & $(0.007)$ \\
\hline \multirow[t]{2}{*}{$\begin{array}{l}\text { industrialization } \\
\text { level }\end{array}$} & 0.005 & 0.019 & 0.011 & 0.010 & 0.009 \\
\hline & $(0.013)$ & $(0.020)$ & $(0.011)$ & $(0.012)$ & $(0.010)$ \\
\hline \multirow[t]{2}{*}{$R \mathcal{E D}$ intensity } & 0.062 & 0.053 & 0.061 & 0.065 & 0.041 \\
\hline & $(0.118)$ & $(0.124)$ & $(0.089)$ & $(0.099)$ & $(0.123)$ \\
\hline \multirow[t]{2}{*}{ patent stock } & 0.131 & -0.026 & -0.057 & -0.073 & -0.031 \\
\hline & $(0.185)$ & $(0.313)$ & $(0.131)$ & $(0.125)$ & $(0.095)$ \\
\hline \multirow[t]{2}{*}{ human capital } & 0.044 & 0.050 & 0.018 & 0.016 & 0.014 \\
\hline & $(0.030)$ & $(0.030)$ & $(0.023)$ & $(0.026)$ & $(0.026)$ \\
\hline
\end{tabular}

23 Robustness checks' results available upon request to the author. 


\begin{tabular}{lccccc}
\hline Variables & \multicolumn{5}{c}{ Estimator } \\
\cline { 2 - 6 } & $\begin{array}{c}\text { Random } \\
\text { Effects }\end{array}$ & $\begin{array}{c}\text { Fixed } \\
\text { Effects }\end{array}$ & $\begin{array}{c}\text { Fixed } \\
\text { Effects }\end{array}$ & $\begin{array}{c}\text { Arellano- } \\
\text { Bond }\end{array}$ & LSDVC \\
\hline Observations & 294 & 294 & 294 & 294 & 294 \\
R-squared & 0.7942 & 0.350 & 0.581 & 33 & 33 \\
No. of countries & 33 & 33 & 33 & Yes & Yes \\
Country FE & Yes & Yes & Yes & Yes & Yes \\
Year dummy & Yes & Yes & Yes & & \\
Hausman Test & & & $\mathrm{X}^{2}=25.45 ; \mathrm{P}>\mathrm{X}^{2}=0.1130$ & \\
\hline
\end{tabular}

Source: Calculated by the author based on Araujo (2010); Epopatstat Online (2015); Gwartney, Lawson and Hall (2015); OECD (2014a, 2014b); Stewart, Warda and Atkinson (2012); WIPO (2018); World Bank ([2017]).

Note: Standard errors in parentheses. $* * * p<0.01, * * p<0.05, * p<0.1$. Coefficient of the constant variable not presented. Reported results of the Hausman Test considered the static specification (columns 1 and 2).

\section{Discussion of the Results and Policy Implications}

The quantitative study described in the previous section does not provide evidence that tax incentives established by the Brazilian government has attracted international 'footloose RED' from alternative host countries. Results suggest that the Brazilian tax policy has no significant correlation with investments directed to other countries, thus leaving no empirical basis to maintain that MNEs took funds from alternative destinations to invest in innovation in Brazil because of the beneficial fiscal treatment. The fact that regressions using two distinct indicators of RED investment (along with a group of robustness checks) point to the same direction substantially strengthen such conclusion.

Data discussed in section 2.1 indicate that cross-border innovation has been on the rise in the last decades as multinational groups have been internationalizing a greater part of their RED activities. Additionally, the Brazilian market became more attractive and has gained importance in the international economy during this period. It is likely that the increase in foreign innovation funds directed to Brazil is better explained by these general trends rather than by corporate tax planning.

These findings provide interesting insights in light of the literature discussed throughout this paper. First, the lack of evidence of effects on international 'footloose RED' is in accordance with the findings of surveys with Brazilian MNEs' affiliates that indicate that tax incentives are not of primary importance in attrac- 
ting resources for RED from parent companies (GALINA; CAMILLO; CONSONI, 2011; QUEIROZ, 2011; ARBACHE; GOLDSTEIN; MARQUES, 2011; ARRUDA; BARCELLOS; TUMELERO, 2014).

Focusing on the economic literature on impact of innovation tax policies, this study does not provide support to the argument that these incentives work as "beggar-thy-neighbor' schemes, in line with the arguments and evidence presented by Athukorala and Kohpaiboon (2006) and Thomson (2009). It should be stressed that these results are case specific and not applicable to all countries. Loss of generality, however, is the cost to consider the conclusions fairly robust for the Brazilian case.

The positive signs and statistical significance of the coefficients of variables representing demand-side factors (total sales or GDP levels) of the host countries are also noteworthy. They confirm previous results that the majority of RED is mainly attracted by the market potential. The consulted literature on internationalization of RED takes these features as typical of adaptive or "market seeking" RED (OECD, 2011; UNCTAD, 2005a; DUNNING, 1994). This is still the dominant type of innovation transferred by multinational groups to affiliates or contractors in other countries. It is largely driven by market proximity, and its purpose is mainly production support and adaptation to local conditions, consumers' preferences or existing regulations.

The coefficients of variables representing the supply-side of innovation or quality of countries' innovation systems (human capital, high technology exports, patent stock and RED expenditure) are not statistically significant in either models. This can be interpreted as another evidence of the adaptive nature of great part of the RED currently internationalized. Studies that used a more restricted sample comprised exclusively of developed economies found significant results for supply of skilled researchers (THOMSON, 2009), capital stock (THOMSON, 2009), and RED intensity (ATHUKORALA; KOHPAIBOON, 2006), suggesting that, in these cases, international investment may be dedicated to a more innovative type of RED.

The main policy implication of the study is that, in the case of Brazil, fiscal benefits do not seem to be the most appropriate policy tool for attracting 'footloose RED' or for competing at the international level for innovation funds that are not specific to supporting local activities. This study provides grounds for maintaining that, up to this point, the reduction of tax costs was not a driver to pull investment from other sources towards facilities and affiliates in the country.

The adaptive orientation of RED performed in the country (as discussed in section 3.1) suggests that boosting the local market seem to be the most straight-forward way to bring more innovation funds to local affiliates. The positive and significant coefficients for sales levels and market size (GDP) provide empirical support for this conclusion. However, while such investment may be relevant to 
increase the 'absorptive capacity'24 of local firms (RADOSEVIC; YORUK, 2014), it must be acknowledged that they have a limited role in developing or fostering innovative RED. Recent literature suggests that international investment and knowledge inflow are relevant for technology upgrading, but they are hardly a sufficient condition or driver of such development (RADOSEVIC; YORUK, 2015). The main challenge rests in devising a national strategy in which these investments supplement or help nurturing more complex and technology frontier innovation.

In the case of more central or technology-complex RED , the literature suggests that supply-side factors, such as availability of a highly qualified workforce, research infrastructure or technology clusters, play a more prominent role. Policies aiming to foster investment in these areas seem to be a more promising choice for making the country more attractive for this type of RED. Such a conclusion is in accordance with previously mentioned surveys (ARRUDA; BARCELLOS; TUMELERO, 2014; GALINA; CAMILLO; CONSONI, 2011; ARBACHE; GOLDSTEIN; MARQUES, 2011) and the available data on the poor quality of the country's human capital, especially the pool of workforce specialized in engineering related areas (WEF, 2015). The recent literature on co-location effects also suggest that enlarging the base of activities of local affiliates in global value chains should also help to attract innovation investments to the country (BELDERBOS et al., 2016).

The fact that the fiscal policy did not attract "footloose" RED does not mean that it is meaningless or without impact. Recent studies for the Brazilian policy (following the conclusions of international research) identified the positive impact of these incentives, increasing the amount of RED investment, although with different levels of elasticities (SHIMADA, 2014; KANNEBLEY JR.; PORTO, 2012).

On the other hand, the results presented herein cast doubt on the role of this policy tool in attracting international investments that fosters technology efforts beyond adaptation of products and diversification of technology. These findings are consistent with the argument that fiscal incentives are closer to a 'market failure' rationale of innovation policy (KÖHLER; LAREDO; RAMMER, 2012), as their main purpose is to compensate for knowledge spillovers. For this reason, proponents of a broader concept of innovation policy based on an evolutionary or Neo-Schumpeterian approach do not consider tax incentives as an appropriate tool for meeting broader societal challenges or enhancing firms' innovation possibilities (METCALFE, 1994; MAZZUCATO, 2011). Finally, the results are also relevant from an international cooperation perspective. They suggest the worries expressed by the OECD $(2013 a, 2014 a)$ that international competition should lead to a zero-sum game and overall reduction of revenues may be unfounded for the Brazilian case. These findings are aligned with the branch of literature that emphasizes

24 The 'absorptive capacity' of a firm refers to its ability to find value in new information, assimilating and applying it to commercial ends (COHEN; LEVINTHAL, 1990). 
macroeconomic and market size variables as attraction factors for international RED (THOMSON, 2009; ATHUKORALA; KOHPAIBOON, 2006). Claims for coordination rules at the international level (OECD, 2013a) should be considered carefully, as they may inefficiently hinder countries in adopting tax incentives that increase their international RED levels with no negative impact on the flow to other economies.

\section{References}

ARAUJO, B. C. Incentivos fiscais à pesquisa e desenvolvimento e custos de inovação no Brasil. Radar: Tecnologia, Produção e Comércio Exterior, n.9, p. 3-11, 2010.

ARBACHE, J.; GOLDSTEIN, A.; MARQUES, F. Attractiveness for innovation: the case of Brazil. In: INNOVATION POLICY FOR INCLUSIVE GROWTH: TECHNICAL CONFERENCE ON TRENDS, POLICIES AND EVALUATION, 2011, Rio de Janeiro. Proceedings [...]. Rio de Janeiro: BNDES, 2011. Available at: http://www.bndes.gov.br/SiteBNDES/export/sites/ default/bndes_pt/Galerias/Arquivos/empresa/download/inovacao_presentation_07.pdf. Access on: 15 jun. 2019.

ARELLANO, M.; BOND, S. Some tests of specification for panel data: Monte Carlo evidence and an application to employment equations. Review of Economic Studies, v. 58, p.277-297, 1991.

ARRUDA, C.; BARCELLOS, E.; TUMELERO, C. Relatório do projeto "Centro de Referência em Inovação (CRI) Multinacionais”. Nova Lima: Fundação Dom Cabral (FDC), 2014.

ASSEMBLÉE NATIONALE. Rapport d information en conclusion des travaux de la mission d’évaluation et de contrôle sur le credit d`impôt recherché. Rapport, Paris, n. 2686, 2010.

ATHUKORALA, P.; KOHPAIBOON, A. Multinational enterprises and globalization of $R \mathcal{}$ D:astudy of U.S-based firms. Departmental working papers from the Australian National University, 2006.

BELDERBOS, R.; LYKOGIANNI, E.; VEUGELERS, R. Strategic RED location by multinational firms: spillovers, technology sourcing, and competition. Journal of Economics $\mathcal{B}$ Management Strategy, v. 17, n. 3, p. 759-779, 2008.

BELDERBOS, R. et al. Academic research strengths and multinational firms' foreign RED location decisions: evidence from RED investments in European regions. Environment and planning A, v. 46, n. 4, p. 920-942, 2014.

BELDERBOS, R. et al. Where to locate innovative activities in global value chains: does co-location matter? OECD Science, Technology and Industry Policy Papers, Paris, n. 30, 2016.

BLOOM, N.; GRIFFITH, R. The internationalisation of UK REDD. Fiscal Studies, v. 22, p. 337355, 2001.

BRUNO, G. S. F. Estimation and inference in dynamic unbalanced panel data models with a small number of individuals. Milan: Università Bocconi-CESPRI, 2005. (WP, 165) 
BUN, M. J. G.; KIVIET, J. F. On the diminishing returns of higher order terms in asymptotic expansions of bias. Economics Letters, v. 79, p. 145-152, 2003.

CANTWELL, J.; JANNE, O. Technological globalisation and innovative centres: the role of corporate technological leadership and locational hierarchy. Research Policy, v. 28, p. 119144, 1999.

CANTWELL, J.; PISCITELLO, L. The location of technological activities of MNCs in European regions: the role of spillovers and local competencies. Journal of International Management, v. 8, n. 1, p. 69-96, 2002.

COHEN, W. M.; LEVINTHAL, D. A. Absorptive capacity: a new perspective on learning and innovation. Administrative Science Quarterly, v. 35, n. 1, p. 128-152, 1990.

COSTA, I. Technological learning, REDD and foreign affiliates in Brazil. In: EXPERT MEETING, 2005, Geneva. Globalization Of RED and developing countries: proceedings [...]. New York: UN, 2005.

DE RASSENFOSSE, G. et al. The worldwide count of priority patents: a new indicator of inventive activity. Research Policy, v. 42, n. 3, p. 720-737, 2013.

DIAS, A. A. et al. Atividades de PED das multinacionais farmacêuticas no Brasil. Sistemas $\mathcal{E}$ Gestão, v. 8, p. 458-468, 2013.

DISCHINGER, M.; RIEDEL, N. The role of headquarters firms in multinational profit shifting strategies. [S.1.], 2010. Available at: https://epub.ub.uni-muenchen.de/11352/1/dischinger riedel_2010_HQs_PS.pdf. Access on: 15 jun. 2019.

DUNNING, J. H. American investment in British manufacturing industry. London: George Allen and Unwin, 1958.

DUNNING, J. H. Toward an eclectic theory of international production: some empirical tests. Journal of International Business Studies, v. 11, n. 1, p. 9-31, 1980.

DUNNING, J. H. The eclectic paradigm of international production: a restatement and some possible extensions. Journal of International Business Studies, v. 19, p. 1-31, 1988.

DUNNING, J. H. Multinational enterprises and the globalization of innovatory capacity. Research Policy, v. 23, p. 67-88, 1994.

DUNNING, J. H.; NARULA, R. The RED activities of foreign firms in the United States. International Studies of Management \& Organization, v. 25, n. 1-2, p. 39-74, 1995.

EUROPEAN COMISSION. Internationalisation of business investments in RED and analysis of their economic impact. Luxembourg: EC, 2012.

EUROPEAN COMISSION. A study on RED tax incentives: final report. Hague, 2014.

EUROPEAN COMISSION. Horizon 2020 indicators: assessing the results and impact of horizon. Luxembourg: Publications Office of the European Union, 2015. 
EDLER, J.; MEYER-KRAHMER, F.; REGER, G. Changes in the strategic management of technology: results of a global benchmarking study. RED Management, v. 32, p. 149-163, 2002.

EPOPATSTAT ONLINE. [S.1.]: European Patent Office, 2015. Available at: https://www.epo. org/searching-for-patents/business/patstat.html\#tab1. Access on: 25 jun. 2019.

GALINA, S. V.; CAMILLO, E.; CONSONI, F. Por que empresas multinacionais investem em PEBD em países em desenvolvimento? Uma análise entre fatores de atração versus tipo de PED realizada no Brasil. In: ENCONTRO DA ANPAD, 35., 2011, Rio de Janeiro. Anais eletrônicos [...]. Rio de Janeiro: ANPAD, 2011.

GWARTNEY, J.; LAWSON, R.; HALL, J. Economic freedom of the world: 2015 annual report [Dataset]. Fraser Institute, 2015. Available at: http:/www.freetheworld.com/release.html. Access on: 25 jun. 2019.

HALL, B. H. The internationalization of RED. 2011. Available at: http://ssrn.com/ abstract $=2179941$. Access on: 25 jun. 2019.

HATEM, F. Location criteria of activities related to innovation: an econometric study on OECD AFA and FATS Data Bases. [S.1.]: DSTI, 2009. Available at: http://www.fabricehatem. fr/fh-medias/Etudes/oecd2009.pdf. Access on: 15 jun. 2019.

HATEM, F.; PY, L. Location factors in the activities related to innovation of multinationals: a literature review. OECD Directorate For Science, Technology And Industry OECD DSTI/IND/ WPGI(2008)6, 2008. Available at: http://fabrice.hatem.free.fr/images/stories/publications/ ocdelocal.pdf. Access on 05 set.2019.

HINES JR., J. R. On the sensitivity of RED to delicate tax changes: the behavior of U.S. Multinationals in the 1980s. In: GIOVANNINI, A.; HUBBARD, R. G.; SLEMROD, J.(eds.). Studies in international taxation. University of Chicago, 1993.

HINES JR., J. R. No place like home: tax incentives and the location of RED by American multinationals. In: POTERBA, J. M. (ed.). Tax policy and the economy. Cambridge: MIT Press, 1994.

HINES JR., J. R. Taxes, technology transfer, and the RED activities of multinational firms. In: FELDSTEIN, M.; HINES Jr., J. R. ; HUBBARD, R. G.(eds.) The effects of taxation on multinational corporations. University of Chicago, 1995.

HINES JR., J. R.; JAFFE, A. B. International taxation and the location of inventive activity. In: international taxation and multinational activity. University of Chicago Press, 2000.

HIRATUKA, C. Foreign direct investment and transnational corporations in Brazil: recent trends and impacts on economic development. Working Group on Development and Environment in the Americas, discussion paper number 10, 2008.

HIRSCHEY, R. C.; CAVES, R. E. Research and transfer of technology by multinational enterprises. Oxford Bulletin of Economics and Statistics, v. 43, n. 2, p. 115-130, 1981.

IBGE. Pesquisa de inovação 2011. Rio de Janeiro: IBGE, 2013. 
JINDRA, B.; HASSAN, S. S.; CANTNER, U. What does location choice reveal about knowledge-seeking strategies of emerging market multinationals in the EU? International Business Review, v. 25, p. 204-220, 2016.

JONES, G. K.; TEEGEN, H. J. Factors affecting foreign REDD location decisions: management and host policy implications. International Journal of Technology Management, v. 25, n. 8, p. 791-813, 2003.

JUDSON, R. A.; OWEN, A. L. Estimating dynamic panel data models: a guide for macroeconomists. Economics Letters, v. 65, p. 9-15, 1999.

KANNEBLEY Jr., S.; PORTO, G. Incentivos fiscais à pesquisa, desenvolvimento e inovação no Brasil: uma avaliação das políticas recentes. Banco Interamericano de Desenvolvimento. IDB-DP-236, 2012.

KNOLL, B.; BAUMANN, M.; RIEDEL, N. The global effects of R\&D tax incentives: evidence from micro-data. [S.1.]: Leibniz-Informationszentrum Wirtschaft, 2014.

KÖLER, C.; LAREDO, P.; RAMMER, C. The impact and effectiveness of fiscal incentives for RED. In: EDLER, J.(org.). Compendium of evidence on the effectiveness of innovation policy intervention. [S.1.]: Manchester Institute of Innovation Research (MIoIR), 2012.

KUMAR, N. Determinants of location of overseas RED activity of multinational enterprises: the case of US and Japanese corporations. Research Policy, v. 30, n. 1, p. 159-174, 2001.

LE BAS, C.; SIERRA, C. Location versus home country advantages' in RED activities: some further results on multinationals' locational strategies. Research Policy, v. 31, p. 589-609, 2002.

MAZZUCATO, M. The entrepreneurial state. London: Demos, 2011.

MCKENZIE, K. J.; SERSHUN, N. Taxation and RED: an investigation of the push and the pull effects. Canadian Public Policy, v. 36, p. 307-324, 2010.

METCALFE, J. S. Evolutionary economics and technology policy. The Economic Journal, v. 104, n. 425, p. 931-944, 1994.

OECD. The internationalization of Business RED: evidence, impacts and implications. Paris: OECD Publishing, 2008.

OECD. Attractiveness for innovation: location factors for international investment. Paris: OECD Publishing, 2011.

OECD. Supporting investment in knowledge capital, growth and innovation. Paris: OECD Publishing, 2013a.

OECD. Definition, interpretation and calculation of the B index. 2013b. Available at: https:// www.oecd.org/sti/b-index.pdf. Access on: 25 jun. 2019.

OECD. OECD science, technology and industry Outlook 2014. Paris: OECD Publishing, 2014a.

OECD. RED tax subsidy rate, OECD, 1981-2011 [Dataset]. 2014b. Available at: http://dx.doi. org/10.1787/888933151759. Access on 21 aug. 2019. 
OECD. OECD main science and technology indicators database [Dataset]. 2016. Available at: http://stats.oecd.org/Index.aspx? DataSetCode=MSTI_PUB\#. Access on: 25 junho 2019.

QUEIROZ, S. Obstáculos ao investimento em PEBD de empresas estrangeiras no Brasil. Revista USP, v. 89, p. 244-255, 2011.

RADOSEVIC, S.; YORUK, E. Are there global shifts in the world science base? analysing the catching up and falling behind of world regions. Scientometrics, v. 101, n. 3, p. 1897-1924, 2014.

RADOSEVIC, S.; YORUK, E. Why do we need theory and metrics of technology upgrading? UCL SSEES Economics and Business Working Paper. n.134, 2015.

RUIZ, A. U. Motivações do PEBD transnacional no Brasil e efeitos locais de absorção de conhecimento. Revista Brasileira de Inovação, v. 14, n. 2, p. 415-442, 2015.

SAFARIAN, A. E. Foreign ownership of canadian industry. Toronto: McGraw Hill, 1966.

SHIMADA, E. Efetividade da lei do bem no estímulo ao investimento em PED: uma análise com dados em painel. 2014. Dissertação (Mestrado ) - Universidade de São Paulo, 2014.

SHIMIZUTANI, S.; TODO, Y. What determines overseas RED activities? The case of Japanese multinational firms. Research Policy, v. 37, n. 3,p. 530-544, 2008.

SIEDSCHLAG, I. et al. What determines the location choice of RED activities by multinational firms? Research Policy,v. 42, p. 1420-1430, 2013.

STEWART, L. A.; WARDA, J.; ATKINSON, R. D. We're \#27!: The United States lags far behind in RED tax incentive generosity. The Information Technology and Innovation Foundation, 2012.

THOMSON, R. Tax policy and the globalisation of RED. The Australian National University Working Papers in Trade and Development, p. 40, 2009.

THOMSON, R. National scientific capacity and RED offshoring. Research Policy, v. 42, p.517528, 2013.

THURSBY, J.; THURSBY, M. Here or there? a survey of factors in multinational RED location. National Academies Press, Washington DC, 2006.

UNCTAD. UNCTAD survey on the internationalization of RED: current patterns and prospects on the internationalization of RED. United Nations: New York and Geneva, p. 165, 2005a.

UNCTAD. World investment report 2005: transnational corporations and the internationalization of REDD. United Nations: New York and Geneva, $2005 \mathrm{~b}$.

UNCTAD. World investment prospects survey 2014-2016. United Nations: New York and Genova, 2014.

U.S. BEA. [Database on] activities of U.S. affiliates of foreign multinational enterprises [Dataset]. [S.1.: BEA, 2016]. Available at: http://www.bea.gov/international/di1fdiop.htm. Access on: 25 junho 2019. 
U.S. TARIFF COMMISSION. Implications of multinational firms for world trade and investment for US trade and labor. Washington, D.C., 1973.

WEF. The human capital report 2015. [S.1.]: WEF, 2015.

WILSON, D. J. Beggar thy neighbor? the in-state, out-of-state, and aggregate effects of RED tax credits. Review of Economics and Statistics, v. 91, n. 2, p. 431-436, 2009.

WIPO. IP statistics data center [dataset]. [S.l.]: WIPO, 2018. Available at: http://ipstats.wipo. int/ipstatv2/index.htm?tab=patent. Access on 15 jun. 2019.

WOOLDRIDGE, J. M. Econometric analysis of cross section and panel data. MIT Press, Massachusetts, 2002.

WORLD BANK. World bank indicators database [Dataset]. [S.l.]: World Bank, [2017]. Available at: http://data.worldbank.org/indicator/NY.GDP.MKTP.CD. Access on 15 jun. 2019.

Recebido em: 08/08/2017. Aceito em: 08/11/2017.

\section{(cc) BY}

